\title{
Soviet meta-jokes: tradition and continuity
}

\author{
Anastasiya Astapova \\ University of Tartu, Estonia \\ anastasiya.astapova@ut.ee
}

\begin{abstract}
This article provides the first published collection and analysis of Soviet meta-jokes, accompanied by a review of meta-joke research, and a discussion of the ways that scholars have understood the term. As far as possible, the Soviet meta-jokes published here appear in chronological order with the goal of showing how, with the help of certain intertextual links, these jokes reflected political and historical changes in joke-telling culture. Soviet meta-jokes captured how joking traditions developed, which joke cycles were especially productive and popular, and how people in the Soviet Union reacted to various jokes. I also show in this article how the characteristics of meta-jokes that have been identified in previous research are applicable to Soviet meta-jokes, and how their political content makes them distinctive from, for instance, mainstream Anglophone meta-jokes. Given the lack of meta-data on the Soviet joking tradition (due to the authoritarian regime), meta-jokes serve as a valuable social commentary on the tradition of Soviet joke-telling. The article concludes with several examples of meta-jokes from post-Soviet countries, demonstrating that such texts remain chiefly political; at the same time, I show how much more complex and sophisticated metajokes have become in the course of their development, both in terms of structure and content. The fieldwork-drawn materials from contemporary Belarus allow me to observe meta-jokes as they are told in a variety of forms and contexts-something impossible for the Soviet jokes (mostly archived without any context). The article documents, among others, multi-level meta-jokes from contemporary Belarus, showing how they keep seemingly old or extinct Soviet jokes topical.
\end{abstract}

Keywords: meta-jokes, Soviet jokes, authoritarian jokes, political humour.

\section{Introduction}

In her book The Unwomanly Face of War (2017), the Nobel Prize-winning writer Svetlana Alexievich reminds us of the following joke which circulated in the Soviet Union after the Second World War:

It's night-time. In the barracks. Prisoners are talking. They ask each other, "Why were you locked up?" One says - for telling the truth. A second - because of my father... And a third 
answers, "For being lazy". What?! They're all surprised. He tells them, "We were sitting at a party in the evening, telling jokes. We got home late. My wife asked me, 'Should we go and denounce them now, or tomorrow?' 'Let's go tomorrow. I want to sleep'. But in the morning they came to take us..."

(Melnichenko 2014: 354; Alexievich 2017: 322). The first available record of this joke dates from the 1950s.

This particular joke was widespread in the Soviet Union, as well as in other socialist countries with repressive regimes, such as Romania and Hungary (Luray 1957: 16; Banc \& Dundes 1986: 23). It evokes a key fact known by everyone even remotely familiar with socialist political jokes, namely that such jokes could often lead to persecution. The bitter humour of such jokes reminds us of potential persecution for joke-telling in a highly creative way: by being a joke about joking, or a meta-joke. Soviet meta-jokes, a considerable corpus of texts from the Soviet tradition, are the main focus of this article, which presents the USSR meta-joke texts and their analysis followed by the examples of continuity in the post-Soviet humour tradition. But first, I shall start by defining the term meta-joke, as the precise meaning of the term has varied in scholarly tradition.

\section{The term meta-joke}

It is quite obvious that meta-jokes cannot be created or understood without establishing or identifying the intertextual references to previous jokes. Intertextuality involves a dialogue among several texts (Kristeva 1980: 65), a relationship between a particular text and a prior discourse (Briggs \& Bauman 1992: 147). After all, intertextuality is a key asset of the jokes per se, as jokes are funny due to their choice of intertextual links to political realities or texts belonging to other genres (Tsakona 2018). As such, some scholars understand all humour as meta-humorous (Norrick 1989). For instance, in his dissertation on Soviet jokes, Graham dedicated an entire sub-chapter to what he called metaanekdoty ('meta-jokes') in order to show how jokes engaged critically with Soviet mythological discourse by commenting upon the prevailing myths of the powers that be (Graham 2003: 74). Limón (1983: 202) also documented how what he calls meta-jokes laugh at the legends and the belief into the supernatural. ${ }^{1}$

${ }^{1}$ Limón (1983: 198) presents an example of the following joke (he documented from a Mexican performer) primarily possible due to intertextual links to the popular Vanishing Hitchhiker/Driver urban legend:

Well, once this soldier was hitchhiking on the highway from San Antonio to Laredo. It was at night, and it was very dark on the highway. He was right outside Pearsall and he was real tired, because he had been walking all day. He was walking up a small rise in the road [informant imitates the tired walking motion of the soldier]. Then he saw a car coming moving very slowly and coming to a stop as it came closer to him. Finally it comes to a full stop as it gets to him and so he figured, "Well, I'm going to get a ride!" and so he opened the door, got in and said, "Good evening". But nobody answered and as the car started speeding up, he noticed that there was no driver! All he could see was this old wrinkled hand on the steering wheel! And the car moving faster and faster! And he said, "Oh shit! What am I going to do!" And he was real scared especially when he heard sounds like "Uh, Uh, Uh". [Informant's voice pitch gradually rising]. Finally the car slowed up as it got into Pearsall and at the first stop light, the guy quickly jumped out and ran like hell! And he made his way into a bar to get a drink to calm down. And he sat there terrified and shaking [informant imitates soldier]. After a while this little old man came in and sat next to him, and the soldier said, "Oh sir, I have to talk to somebody, I have to tell you about the awful thing that happened to me!" And, he told the old man everything that happened, about the car, and the hand. When he finished, the old man glared at him and said, [loud voice] "So you're the son of a bitch that got in while I was pushing my car!"” 
While acknowledging the inherent meta-discursive nature of jokes, in this article, I use the term meta-jokes in a different understanding: to denote jokes that explicitly refer to other jokes (or to joking tradition per se). When meta-jokes in this understanding are performed, the listener follows the script of a common or garden-path joke, but suddenly this expectation collides with the script revealing that this is a joke about jokes (Kelley 2015: 207). The comic effect of meta-jokes derives from their breaking of the so-called fourth wall. The term fourth wall originates from theatrical parlance for the invisible imagined barrier in between the actors and the audience, with the actors behaving as though they do not realize that there is the audience behind the fourth wall. This convention is however sometimes broken, as when, for example, an actor addresses the audience directly or refers to the play as a play. A similar process takes place when jokes recognise themselves as jokes: the fourth wall is broken by means of meta-reference (Dundes 2007: 82).

There are some very popular cycles that have existed for quite some time which become self-referential and give rise to meta-jokes. One example in the USA is that of jokes about lawyers: these became so popular and widespread that at some point meta-jokes about lawyer jokes also appeared (Galanter 2005: 3). Other famous examples of joke cycles which have given rise to meta-jokes include Jewish jokes (Finkin 2009) or walks-into-a-bar jokes (Kelley 2015). The following joke references the popular travelling salesman joke cycle, in which the farmer often offers the only available space in his house, his daughter's or wife's room, and the salesman then proceeds to seduce either of the women:

It was a dark and stormy night and this guy goes up to this old farm house. He's a salesman and he says to the farmer, "I'm a salesman, my car broke down, and I need a place to stay". And the farmer says, "That's all right, but there's just one thing, we have no extra rooms to spare so you'll have to sleep with my son". And the salesman says, "Oh my God, I must be in the wrong joke."

(Dundes 2007: 82)

The potential teller of this joke should assume the meta-joke recipient's knowledge of the original cycle of jokes, but instead of telling this common or garden-path joke, the joke-teller merely refers to it, bringing it to the attention of the joke recipient. In fact, one could say that a joke-teller tells two jokes in one.

Another example comes from a comprehensive article on meta-jokes in American culture written by Kelley (2015). He calls the following joke "self-referential", due to its reference to the popular "walking into a bar" frame:

A priest, a rabbi, and a minister walk into a bar. The bartender looks up and says, "Hey, what is this-some kind of joke?"

The joke brings in the typical joke situation (walking into a bar) and typical joke protagonists yet in an unexpected bundle. Then comes another surprise: the observation of the bartender that this is some kind of a joke. This double incongruity contributes to its funniness and success (Kelley 2015: 206).

In his article, Kelley also convincingly demonstrates how meta-jokes have become an important part of the Anglophone popular culture. For instance, many stand-up comedians have made meta-jokes a pillar of their success (Kelley 2015: 207). Among these is Jimmy Carr whose meta-joke repertoire includes a joke: 
People always say: 'You're a comedian, tell us a joke.' They don't say: 'You're an MP, tell us a lie."”

(The Guardian 2003)

Similarly, meta-jokes have become the essential repertoire of Anglophone popular late-night television shows. Such meta-jokes are usually highly topical, as the following example shows, among others. In response to American journalist Megyn Kelly who claimed that Santa Claus was white on Fox News, the CNN show The Colbert Report hosted a discussion panel with four different multicultural Santas, prompting Stephen Colbert to weigh in:

One white, one black, one Latino, and one Filipino Santa? That reminds me of a great joke I can only tell to a white Santa."

(The Colbert Report 2013)

Colbert's meta-joke manipulated the familiar multi-ethnic slur template and relied on the allusion to a (non-existent) joke that never was told (Kelley 2015: 210). ${ }^{2}$

This example also reveals another key function of meta-jokes, that of interrogating the boundaries of what is considered to be appropriate: to what extent sexist, ethnic, or political jokes are permissible (Kelley 2015: 211). By referring to shop-worn formulas, meta-jokes transgress stereotypes and probe the boundaries between good and bad taste humour (Hariman 2008: 247). This, along with many other examples, confirm not only the formal but also semantic reflexivity and self-consciousness of meta-jokes that has been recognised by many scholars (Terts 1978; Kelley 2015).

Alan Dundes called the reflexivity of meta-jokes "oral criticism" implying that metafolklore bears an important social commentary. The oral criticism of meta-jokes assesses various aspects of jokes, such as unsuccessful attempts at humour, the prevalence of certain humorous topics, or the nature of a joke-telling tradition itself (Dundes 2007: 77-87). While some meta-jokes, being an end to themselves, have a primary aesthetic function, for others, the commentary of the meta section may convey an important social message. For instance, the joke about salesman cited above comments, according to Dundes, is on the substitution of homosexuality for heterosexuality, which is particularly significant in the light of the cultural taboo against homosexual activities. The mere suggestion of such activities to a travelling salesman is so shocking as to call a halt to the story. At the very mention of homosexuality, the American man wants out because the activity is "wrong", the salesman is in the wrong joke (Dundes 2007: 83).

Finally, meta-humour is known to demarcate the symbolic boundaries of groups by excluding those who do not understand certain intertextual links (Norrick 1989; Gasparov 2010: 205; Hale 2018: 517) or who are otherwise unable to decode meta-humour (Kuipers 2009: 229). Scholars define humour which is not easy for everyone to comprehend as "sophisticated" (Raskin 1985: 46, 136) or "intellectual" (Kuipers 2009: 228), and attribute these qualities to an elitist outcome of intertextuality. The shared knowledge of intertextual links may be "unevenly distributed" and recognition of them may result in "conspiratorial pleasure" (Kuipers 2009: 225, 229; see also Duff 2004; Adami 2012: 141; Tsakona 2018: 2-

${ }^{2}$ Reflexivity, self-awareness, and transgression of meta-jokes also manifest in other popular culture genres, such as sitcoms. The Simpsons or Seinfeld are particularly known for their meta-humour: their comic effect is often achieved by violating the rules of the humorous genre. For instance, the Chinese Restaurant episode of Seinfeld simply consists of the characters waiting, in vain, for a table at a Chinese restaurant. This episode breaks many of the rules of sitcom, such as having a firm pace, short scenes, and a plot with a clear denouement. The humorous effect of this episode depends on recognising the reference to the failed comedy genre (Kuipers 2009: 228). 
3). Exemplary processes of group inclusion and exclusion via meta-jokes takes place in the expressive North American tradition of humorous narratives about practical jokes. Bauman (2004: 115) and Smith (2009) have illustrated how such humorous performances by tricksters recount their practical jokes on a certain member of the community, or how the butts of the joke may be fooled into thinking that they have been made a fool of publicly. Not sharing the group's understanding of what is so funny about them, the butts of the humour may be automatically excluded from the group.

The social comments of meta-jokes may be very useful for the study of those joking traditions we know little about, such as political jokes in repressive regimes. For instance, very few collections of political jokes in authoritarian regimes jokes include the joke-tellers' comments about them, information which could reveal the attitudes to and the functions of jokes. Due to the limited number of such records, it is still unclear why people have dared to undertake the risky business of political joking despite the fear of punishment (Oring 2004). Given how little metadata we have about the Soviet joking tradition (Melnichenko 2014: 2432), attention to meta-jokes may provide otherwise unavailable knowledge about topics such as context, oral criticism, reflexivity, and the symbolic boundaries demarcated by humour. They may reveal a hitherto-overlooked folk commentary on why jokes matter.

\section{Soviet meta-jokes}

In this article, I intend to examine Soviet meta-jokes from what is perhaps the most comprehensive, recent, and exhaustive collection of jokes available from a repressive regime. This collection by Misha Melnichenko (2014) features 5862 joke-types that circulated in the USSR from 1917 to 1991; many of these joke-types are also represented by several variants. The introduction of the book as well as annotations to jokes present novel commentaries on the peculiarities of Soviet everyday joking, the history of certain joke loans and Soviet emigrant impact on the Soviet joke-telling; to my knowledge, the detailed analysis of veracity and authenticity of the Soviet joke collections in different sources in the book is the first of its kind. The author provides lots of possibilities for further analysis of the jokes he collected via the user-friendly name- and theme-indices.

Melnichenko drew jokes from a variety of sources: mass media publications (especially those by Soviet emigres), collections of jokes published in both the USSR and abroad (in places as various as Riga or Buenos Aires from the 1920s onwards), official documents (court cases and reports on joke-telling; reports on public opinion), collections of jokes gathered by professional folklorists, diaries, memoirs, fiction, videos of entertaining performances (e.g. by clowns), and other video materials (feature films, documentaries, TV shows, interviews). While the majority of the texts were in Russian, over a thousand of them were recorded in other languages: English, Hebrew, Ukrainian, and Polish. Melnichenko organised his collection along thematic lines, including a whole section of meta-jokes called Anekdotchiki ('Joke-tellers'), with 27 plots. More meta-jokes are scattered in other assorted thematic parts of this 1533-page book. While meta-jokes from Melnichenko's collection comprise the major material for analysis for this article, I also draw upon various other academic publications on Soviet jokes in which I have encountered meta-jokes.

In handling these texts, I have translated the meta-jokes and supplied the year of their first recording when available (using the notation $n . d$. when such data is not available). In rare cases, where for instance, a joke is recorded in memoirs which an author was writing over several years, I mention the whole time interval, e.g. "1955-1958". Where certain 
elements of a joke require comment or where certain words from the Russian original are worth mentioning, these are provided in square brackets.

For the sake of clarity, I publish Soviet meta-jokes in a chronological order here, as much as this is possible. This cannot always be done, as we sometimes do not know the dates of the jokes' recording. Sometimes, in case the meta-jokes are on the same topic, for the sake of giving more examples, I tend to group them together, even though this breaks the chronological principle. After all, even if we know the date of the first documentation of a meta-joke, this is often simply the earliest date available, whereas the joke may have circulated earlier. Furthermore, we need to remember that political jokes easily changed their protagonists from Stalin to Khrushchev, to Brezhnev, etc., and might also have been popular at a much later date, too. Most probably, meta-jokes appeared in plenty in the Stalinist years, following the outburst of Soviet political jokes.

\subsection{Stalin era meta-jokes}

In the first decade of the Soviet Union, the powers-that-be ignored jokes. With, however, the coming of Stalin to power in the 1920s, political jokes became illegal. Joke-tellers, and those who did not report on them, were liable to prosecution under Article 58.10 of the legal code, "Anti-Soviet agitation". In 1935, for instance, 7\% of court cases under Article 58.10 related to the performance and dissemination of anti-Soviet jokes, songs, rhymes, or simply of political folklore (Arkhipova \& Melnichenko 2011: 36). The first written accounts or rumours of people being punished for defying state power by telling jokes spread at the same time. For example, the following joke was documented in a court case: its teller was subsequently sentenced to 10 years in prison. It reminds of later jokes also told about Stalin, in which the protagonist, a simple man, unwittingly saves Stalin (e.g. from drowning) and asks him not to tell about it around, as the man's fellows will condemn him for his 'deed'.

Stalin asked a shoemaker to make shoes for him: "If you make good shoes, I will order that the newspapers write about you". The shoemaker answered: "Please, do not order this! People will kill me."

(Arkhipova \& Melnichenko 2011: 246), 1930s

Since then, jokes about punishments for joke-telling constituted a major part of the Soviet meta-joke repertoire.

"What is the hobby of Stalin?"

"He collects jokes about himself".

"And how many has he collected?"

"Two [GULAG] camps".

(Melnichenko 2014: 661), 1947-1948.

A judge laughs:

"I have heard such a great joke!"

"Tell it!"

"I can't: I have just sentenced the joke-teller to 10 years for it".

(Melnichenko 2014: 661), the beginning of 1950s.

The topic of getting into the camps for joke-telling is one of the most persistent of the metajokes especially in the era of Stalin, although he is far from being the only protagonist of such jokes. Another joke was told about the colleague of Stalin, Lavrenty Beria, Head of the People's Commissariat for Internal Affairs, the Soviet ministry conducting regular police 
work and overseeing the country's prisons and labour camps. Beria was known for being particularly prone to violence and for overseeing the vast expansion of the GULAG camps:

Beria is the biggest fan of jokes. He collects jokes together with their tellers.

(Melnichenko 2014: 661), n.d.

There is a related meta-joke about the Baikal-Amur Mainline, a broad-gauge railway line going through Siberia, mostly built between 1938 and 1984. Its construction largely relied on the forced labour of GULAG inmates, in particular from the Bamlag camp (Baikal Amur Corrective Labour Camp) of the GULAG system. The following joke reminds that joketellers and joke-listeners who failed to report on joke-telling might have been among the construction workers:

When the tunnel was complete for the Baikal-Amur Mainline, those who had been telling jokes on one side, and those who had listened to them on the other side, finally met.

(Melnichenko 2014: 660), 1950s.

Many meta-jokes on the persecution of joke-tellers rely on wordplay involving the two meanings/senses of the word sidet', which in Russian means, more generally, 'to sit' and, more specifically, 'to be in prison'. Such jokes continued well past the Stalinist period until the end of the Soviet Union:

"Who sits and composes jokes?"

"Those who compose, sit".

(Melnichenko 2014: 660), 1938.

The NKVD employee asked a man who made a joke about the Soviet authorities, "Do you know what the difference between you and the bus is?"

"No".

"It is that the bus stays in the bus stop, and you will soon sit".

(Melnichenko 2014: 355), 1977.

"How are the jokes created? Do people sit and compose them?"

"No, at first they compose them, and then they sit".

(Melnichenko 2014: 660), n.d.

"Will they get people seated for jokes [Liudei budut sazhat' za anekdoty]?"

"Not for jokes, but behind bars" [Ne za akekdoty, a za reshetku]. ${ }^{3}$

(Melnichenko 2014: 660), the beginning of 1960s.

An important part of meta-jokes about the persecution for joke-telling is the motif of reporting, also illustrated by the very first joke in this article (see Section 1). According to the following joke, two people who laugh have reported on those who now 'sit'. Interestingly, the joke is also telling of the importance attributed to the practice of telling jokes as an activity full of joy; it is compared to driving for fun or having sex:

"How do young people have fun in America?"

"Five guys and five girls get together in pairs in cars and drive down a steep mountain. After this, two of them end up in hospital, the rest sit and laugh".

${ }^{3}$ (The joke is also based on the dual meaning of the preposition $z a$ in Russian: (1) 'for' [in the phrase for jokes] and (2) 'behind' [in behind bars]). 
"How do young people have fun in France?"

"Five guys and five girls get together and have sex. One of them has syphilis. After this, two of them end up on medication, and the rest sit and laugh".

"And how do young people have fun in the Soviet Union?"

"Five guys and five girls get together and tell political jokes. After this, everybody sits, and two laugh."

(Melnichenko 2014: 660), 1966.

An American, a Frenchman, and a Russian boast of how brave they are. "Every fifth American gets into a car accident," an American says, "but despite this we are not afraid of driving cars".

"Every fourth French prostitute has a venereal disease", a Frenchman says, "but despite this, we are not afraid of visiting brothels".

"And in our country", a Russian says, "every third Russian is a snitch, but we are not afraid of telling political jokes".

(Melnichenko 2014: 660-661), n.d.

Sometimes, the jokes suggest that professional secret police agents were involved in surveilling joke-telling:

There were two men in a train compartment, telling political jokes. The first one says, "Wait, I'll just put in a new cassette" [in order to continue recording the jokes]. The second one replies, "That's okay, you can use mine to make a copy".

(Melnichenko 2014: 355), n.d.

Some people are telling political jokes at a party. Between the laughter, somebody says, "Can't you people be a little quieter, I am trying to write things down".

"How do you manage to write everything down?"

"I only write the initials" [to report on joke-tellers afterwards].

(Melnichenko 2014: 355), n.d.

"What is the difference in between caution and cowardice?"

"When I don't tell jokes, this is caution, and when my colleague does not, this is cowardice".

(Melnichenko 2014: 660), 1938.

As the intertextual allusions to socio-political reality reveals, the function of such meta-jokes goes beyond entertainment and humour: they undoubtedly served as cautionary tales. They were the sources of shared common knowledge about the danger of surveillance and the possibility of persecution, letting others know how the regime functioned and how it could be dangerous. As Waterlow (2018: 208-212) shows, Soviet jokes worked as "know-how stories", functioning "to make sense of the mess" and "convey lessons about how the world works". In a way, they were comparable to proverbs in their summing up of wisdom "concisely, pointedly, and memorably" and thus were well-equipped for sense-making. Metajokes were even more reflexive upon the Soviet situation.

In his article on jokes in repressive regimes, Oring (2004) presents one of the many examples of how jokes may serve as cautionary tales as recorded from his respondent, a former manicurist, Klava, who back in 1974 was working in a shop. One day Klava had several clients who were waiting in the shop to have their nails done. One of her regular clients came in without an appointment and Klava asked her to wait until she had finished with her scheduled customers, which the client did. That year was a celebratory year in the communist calendar - a Lenin anniversary - and Klava and her waiting customers exchanged jokes and witticisms - many of them about Lenin. One joke that Klava remembered in her interview with Oring ran: 
When we say Lenin, we mean the Party. When we say the Party, we mean Lenin. And this is how we deal with everything. We say one thing, and we mean something else.

\section{The following are Klava's own words:}

After the two girls left and she [the client] was in the chair. And as I was working on her, she told me, "Klava, do you know who I am?" I said, "Of course, your name is Ludmila Ivanovna". And she said, "Do you know where I work?" "Of course, in the municipal hall". She said, "Do you know what department I work in?" "I have no idea". "It's department number one", which was the KGB. [The customer then told the following joke.] "There was a competition for the best joke about Lenin. And the first prize is ten years to where Lenin used to go to jail, exile. And she looked at me and the smile disappeared from her face, and she told me, 'If I did not value you as my manicurist, I would send you for ten years to where Lenin used to go"'.

That was a decisive moment for Klava who called her family together the same night and told them she was going to submit her application to emigrate from the Soviet Union to Israel. Within four months she had left the country (Oring 2004: 214). This example is very telling not only about the use of meta-jokes, but also about how jokes worked as cautionary tales and shaped people's lives.

During the Second World War, the attention paid to the telling of jokes reduced, but the sense of danger remained around joke-telling. The following joke describes the exchange of Stalin and Georgy Zhukov, a Soviet Red Army General whose actions were recognised as one of the key elements in the defeat of the Nazis. In this joke, Stalin refers to his own threats to Zhukov during the war as just jokes, also showing how vague the border between humour and persecution for it may be:

During the War Stalin invites Zhukov.

"Comrade Zhukov! The Germans are trying to occupy Leningrad. If they occupy the cradle of the Revolution, I will shoot you!"

"May I go?"

"Wait! If you lose Moscow, I will shoot you!"

"May I go and fulfil your orders?"

"Wait! If they overrun Stalingrad, I will shoot you too!"

Zhukov leaves for the front in a hurry.

After some time, during the reception dedicated to the victory over the Nazis, Stalin makes a speech and says, "I want to drink to Zhukov, Chief of General Staff! Zhukov has two great qualities: first, he is a great commander, and second, he understands and values jokes!"

(Melnichenko 2014: 219-220), n.d.

A particular mini-cycle of Stalinist meta-jokes formed around the Soviet politician Karl Radek who was in the Left Opposition against Stalin after Lenin's death. The figure of Radek in jokes and meta-jokes is similar to Little Johnny stock character popular in humour throughout cultures, usually a little boy asking naive yet meaningful and embarrassing questions to adults and thus causing humorous effect. Little Johnny is also known, for instance, as Pepito in Spain and Latin American countries, Vovochka in late Soviet jokes, Bulă in Ceausescu-era Romania. Such tricksters also become the protagonists of meta-jokes, in which they are invited to entertain the ruler, but instead they mock him. Unlike the majority of such tricksters in jokes, Radek was a real-life figure who was reputedly a very witty man. Legends ascribed many jokes to him, something which is borne out by the memoirs of his contemporaries. Then again, folk tradition often focuses upon a single trickster, claiming that he has composed jokes, as, for example, in the attribution of joke 
authorship to Hodja Nasreddin. This is a regular process in the cyclization of joke plots around the figure of the joke-teller or, sometimes simultaneously, the protagonist (Melnichenko 2014: 30). Often Radek jokes sound like accounts of actual joke-telling situations, although now we cannot be sure if they ever happened.

Stalin invites Karl Radek and asks: "Listen, why do you make up jokes about me? I am the leader of the proletariat worldwide!"

"You know I would not be able to make up such a joke!"

(Melnichenko 2014: 232), 1927-1929.

Stalin asks Radek, "Is it you who composes jokes?"

"Yes".

"Tell me a short one".

"Stalin is a gensek [the abbreviation for the General Secretary of the Party]."

(Melnichenko 2014: 232), 1933-1937.

The punchline of the latter joke is an actual description of reality, which, according to Radek, is as absurd as a joke. Radek does not necessarily make jokes on well-known political leaders though:

Once, Radek was seeing off some ambassador who was on his way to the Motherland. They were standing on the platform of the Belarusian Railway Station [in Moscow], but the train whistle blew five minutes before the departure, and as usually happens in such moments, a deep silence fell. To break the silence, the ambassador asked Radek, "Mr Radek! Would you tell us a good joke before the departure?"

"Of course", said Radek. "For example, do you know the difference between your wife and my wife?"

"No", the ambassador replied waiting for a witty answer.

At this moment, the train started moving and gaining speed. Then Radek waving a goodbye said, "But I know..."

(Melnichenko 2014: 329), 1933-1937.

It was already in the Stalinist period that meta-jokes referred to the popularity of certain joke cycles, such as anti-Semitic jokes. The following joke most probably refers to Stalin's 1931 speech in which he condemned anti-Semitism by saying, "[a]nti-Semitism is dangerous for the working people, being a false path that leads them from the right road and lands them in the jungle. Hence Communists, as committed internationalists, cannot but be irreconcilable and sworn enemies of anti-Semitism" (Stalin 1954: 30). The meta-joke uncovers the hypocrisy of Stalin's talk compared to actual state policies and folk sentiments, which were still anti-Semitic:

In their fight against anti-Semitism, the government banned jokes about Jews. To get around the law, this is how the jokes were told, "Once there were two Chinamen. When they left the synagogue..."

(Melnichenko, 2014: 978), 1935.

Another meta-joke illustrates new tendencies found in post-War Soviet humour: the extreme popularity of the General's Wife jokes. During the Second World War, a lot of people from the countryside rose from being young officers to holding the rank of General; after the War, they moved to Moscow together with their families and received elite apartments and high salaries. However, native Muscovites were very critical of their standard of culture, which 
was still very provincial to Muscovites' taste. This is how the jokes about such Generals' wives emerged (comprising enough jokes to make up a separate section in Melnichenko's collection):

Once, in the morning of 1946, Muscovites saw a huge crowd of Jews in the Red Square. All kinds of people were there: men and women, young and old, from the capital and from provinces, even some rabbis and some old-time Jews with sidelocks. The surprised Muscovites ask: "Who are you?"

"We are the Jews from jokes".

"We do not understand. Why from jokes?"

"The Generals' wives have supplanted us".

(Melnichenko, 2014: 905), 1946-1951.

It is hard to measure how numerous Stalinist era meta-jokes were and how often they were told. However, the documented meta-jokes shed light on the peculiarities of the joke-telling tradition and context under Stalin, which mostly involved the fear of being surveilled, reported and punished.

\subsection{Khruschev's era meta-jokes}

The new era of joke-telling, and, consequently, of meta-joking, might have started after the death of Stalin in 1953 and the denunciation of Stalin's cult of personality by Nikita Khrushchev in 1956, a period known as The Thaw. However, historian Vladimir Kozlov shows how superficial the liberal changes were by the help of the following joke, which, once again, plays with the double meaning of 'sitting':

The new situation [of Khrushchev being in power] could be considered a liberation only when compared to the times of Stalin's terror, when life, just like in the old joke, resembled an old tram, in which "half of the people sit and the other half shake and wait to be seated".

(Kozlov 2002: 83)

The folk meta-joking tradition also reflects how minor the changes were:

What is a discounted joke? It is a joke which used to be worth a 10 -year sentence, which now it is only worth 3 years.

(Melnichenko, 2014: 661), 1968.

On the anniversary of Lenin's birth, the KGB announced a competition for the best joke: first prize is to get to meet the person celebrating his anniversary [i.e. a death sentence], second prize is living for seven years at the expense of the state [i.e. in prison], and third prize is a trip to see Lenin's sights [i.e. exile in camps].

(Melnichenko 2014: 179-180), 1959.

The following joke is also about the socio-political context- the need for discipline and blindly obeying the leaders, whether the highest or local officials, who are also able to inflict punishment.

A boss often brings his subordinates together to tell new jokes to them. During one of these meetings, he noticed that while everybody else laughs, a lieutenant sitting in the corner does not. "Why aren't you laughing, lieutenant? Have you lost your sense of humour?"

"I do not have to laugh. I am quitting this job on Friday".

(Melnichenko, 2014: 517), 1962. 
According to the meta-joke, the boss's humour is poor and his jokes are not funny, so the subordinates laugh only out of fear. And the protagonist uncovers it by saying that he does not have to pretend anymore, like others, that the jokes are funny to him. This joke reminds us that "laughter can be an instrument of intimidation, a way to anchor hierarchy, and a powerful tool of totalitarian normalisation and control" (Dobrenko 2014: 7). It also harks back to various attempts the Soviet state made to devise an ideologically-approved humour, such as that found in the satirical magazines that were published in almost every Soviet republic (with Krokodil being the most famous one). The magazines' employees were busy inventing jokes for them, people had to buy them, and both sides had to support the hegemony, by creating humour and pretending to laugh at it.

Folk jokes were nevertheless abundant, many meta-jokes relate:

Khrushchev refused to introduce a six-hour working day because people tell jokes about him anyway for most of their time at work.

(Melnichenko, 2014: 257), 1957.

A new obvious joke theme is that the discourse produced by the Soviet authorities is nothing but a joke, see at least three versions of one joke about this:

KGB arrests a man who composes jokes and brings him in front of Khrushchev. Khrushchev asks, "How do you manage to make up so many jokes even though all people in our country are happy?"

"I did not make up this joke".

(Melnichenko, 2014: 258), 1957.

A Muscovite was making up jokes about Khrushchev. Khrushchev got to know about this, decided to meet him, and asked at the meeting, "Listen, why do you need all these jokes? I am working so hard to make sure that once everyone will be able to eat meat and will live in own apartment. What is so funny about it?"

"I did not make up this joke".

(In yet another version, a joke-teller sees Khrushchev's richly-decorated cabinet and Khrushchev says that soon everyone in the country will be living this way; the joke-teller refers to this as to some kind of joke.)

(Melnichenko, 2014: 258), 1957.

Khrushchev era meta-jokes are scarcer than those of Stalinist of Brezhnev's times; however, this might be due to the lack of their documentation. Despite their scarcity, Khrushchev's jokes, however, evince several important issues. First, this is the ambiguity of the Khrushchev Thaw liberalisation: people still feared the joke-telling. Second, they harked back to the absurdity of the official Soviet humour imposed over the people. Finally, while the Stalinist jokes related to the incongruity between the official rhetoric and the reality, Khrushchev jokes pursued the novel strategy: demonstrating that the Soviet discourse is just a joke.

\subsection{Late Soviet meta-jokes}

The theme of the Soviet official discourse being just a joke persisted throughout the Soviet years, and a lot of versions of such jokes circulated about the next Soviet leader, Leonid Brezhnev (who held office during 1964-1982): 
Brezhnev visits a student dormitory in order to communicate with the people. The discussion does not flow well. Then Brezhnev says, "Shall we drink cognac first and then tell jokes?" Everybody agrees. Brezhnev gives one hundred roubles to one of the students, and the student leaves to buy cognac. The other students are waiting, and Brezhnev does not like the uncomfortable silence, so he says, "Dear students, the Party governed by Central Committee works at the strengthening of the well-being of our people".

"Leonid Ilich, didn't we agree: first the cognac and then the jokes".

(Melnichenko 2014: 276), n.d.

According to another joke, after a relatively soft period of Khrushchev's power, Brezhnev's overtake was equivalent to the return to Stalinists times. To illustrate this, the following joke makes use of the fame of Stalin's moustache and Brezhnev's thick eyebrows (which of course became the object of humour in many other jokes):

"Enough jokes", said Brezhnev with a Georgian accent, while he glued his eyebrows under his nose".

(Melnichenko 2014: 269), 1965.

An important theme of meta-jokes of Brezhnev's era is the mass 1970s Jewish migration from the Soviet Union:

We are fed up with jokes about the emigration of Jews. Let's do things in reverse. A Jew comes to a town and says, "Have all your Jews left? Or is there anybody around?"

(Melnichenko 2014: 1016), 1979.

"Why aren't there jokes about Rabinovich and Shapiro [the most popular surnames for the Jewish protagonists of the jokes] anymore?"

"Rabinovich left for Israel. And Shapiro took his wife's surname and became Petrov".

(Melnichenko 2014: 1024-1025), 1976.

The latter joke also reflects the practice of changing the Jewish surnames for Russian ones followed by many Jews to avoid everyday racism.

Perhaps, the first meta-joke on the Party Leader's death was that about Brezhnev. The following joke is not dated, but most probably it was coined before Brezhnev's death in 1982, in the period when rumours were already spreading about the various ailments he was struggling with:

Two friends meet and start telling jokes to each other. One of them says, "Listen, there is a good joke. The room is all black. There is a red coffin in the middle. Leonid Ilich Brezhnev is put there and the coffin is being hammered shut with golden nails... Have you heard this joke?"

"No, I have not".

"Me neither. But the beginning is so nice".

(Melnichenko 2014: 281-282), n.d.

Brezhnev was succeeded as leader of the Soviet Union first by Yuri Andropov and then by Leonid Chernenko, leaders who ruled the country for a total of only three years (1982-1985). According to the testimony of one of my respondents who lived through the Soviet period, the following joke emerged as in reaction to them, expressing the complaint that their rule was so boring that there were no topics for jokes anymore: 
"Are there new jokes?"

"No".

"What kind of government is it?"

(Melnichenko 2014: 662), n.d.

In fact, there were still many jokes, which also led to rumours about which institution might be composing those jokes. Accounts differed: having studied jokes for seven years, I have heard at least two. One female respondent who lived under the Soviet regime told me that back in the 1970s the professor who taught her at university claimed that there was an institute near Paris specially founded in order to devise jokes that would undermine the Soviet Union. According to another folk theory, political jokes were invented and spread amongst the people by the secret police, in order to provide an acceptable outlet for aggression. The latter seems to be a widespread belief in non-democratic countries with lots of jokes. For instance, Stein (1989: 95) recorded similar story in an interview with an East German:

Most political jokes in GDR do not originate in the folk, but are consciously developed at Party schools and institutions. They are then skilfully introduced to the folk at beer tables and in small social gatherings, and from there they travel by word of mouth ... And the jokes, which allow people to let off steam, also serve the purpose of quieting them.

Such rumours emerged due to the realization that there were many jokes in the Soviet times and the legitimate search for the explanation of their multiplicity. This multiplicity, however, fostered the development of not rumours only, but also of jokes about the abundance and ubiquity of jokes:

"So?" the first person says. "So and so" the second person replies. "I am tired of your political jokes!" the third person says.

(Melnichenko 2014: 661), n.d.

"What shall we do to prevent joke-telling in queues?"

"Abolish queuing perhaps".

(Melnichenko 2014: 661), n.d.

The latter joke also refers to the common shortage of food and other goods in the Soviet Union, which led to queues, and also to the telling of jokes while standing in line in order to kill time. In addition to the ubiquity of jokes, the following joke reminds us of the still omnipresent supervision by the Party Leaders:

In a radio programme, "Letters have reached our editorial staff asking who composes political jokes? This question is of interest for Comrade Ivanov from Leningrad, Comrade Petrov from Kirov, and Comrade Andropov from Moscow".

(Melnichenko 2014: 662), n.d.

The meta-jokes of this time also recognise that political jokes became folk national heritage; they show that jokes can be recognised as group cultural artefacts by, for instance, appealing to the enjoyment of revisiting the joke (Hale 2018: 507).

A company gets together, people in it have given numbers to all the well-known jokes. "Joke number 72!" Laughter follows. "Joke number 354!" Laughter follows. A neophyte has to tell the joke, and as he wants to pretend he knows this tradition, he says out of the blue, "Joke number 
811 !" The others say, "Not in front of the ladies please!" [presumably this number refers to a ribald joke]

(Melnichenko 2014: 661), 1970.

In a prison all the jokes have been told a thousand times, so the inmates number them so as not to waste time.

"Number 67!" Laughter.

"Number 52!" Laughter.

"Number 41 !" One of the inmates starts laughing like mad.

"What's the matter with you?"

"I never heard that one before!"

(Graham 2003: 142), n.d.

Another joke expresses the opposite situation - the condemnation of old and repetitive jokes and an appreciation of new ones:

"Why did Cain kill Abel? Because he told old jokes".

(Bakhtin 1997: 799; Graham 2003: 142), n.d.

Perhaps because the political jokes became too common, or perhaps because the new political leaders seemed boring, Soviet jokes developed on fresh topics. Several persistent joke cycles formed (together with their own meta-jokes). In a somewhat similar manner to walks-into-abar or salesman meta-jokes, they provided commentary upon the most popular joking traditions. Among these were meta-jokes related to jokes about the Soviet militia and army, and their profound stupidity:

"Do you want me to tell a political joke to you?"

"Can't you see that I am a militiaman?"

"That's fine, I can tell it twice and slowly".

(Melnichenko 2014: 670), n.d.

Once, there lived the most dangerous and elusive criminal. Every time a detective caught him, he told the detective a joke, and the detective started to laugh as crazy and died from laughter in fifteen minutes. An English detective died. A French detective died. A Soviet detective listened to the joke and brought the criminal into the cell as if nothing happened. That was on Monday. On Thursday evening, the Soviet detective started to laugh as crazy and in fifteen minutes died from laughter.

(Melnichenko 2014: 670), 1984-1985.

Major Ivanov says to Major Petrov: "How many pies can you eat on an empty stomach?"

"Five".

"That's is not right. You may eat one on an empty stomach, and the rest won't be on an empty stomach anymore".

Major Petrov likes the joke, he found his friend captain Sidorov and asked, "How many pies can you eat on an empty stomach?"

"Seven."

"Oh, that is a pity, if you had said 'five', I could have told you a great joke".

(Melnichenko 2014: 671), n.d.

Another substantial joke cycle was that about the celebrated Russian soldier and Red Army commander in the Russian Civil War, Vasily Ivanovich Chapaev, and his comrades Pet'ka and Anka. Although the first jokes about them appeared in 1930s, following the screening of 
the film Chapaev, the majority of Chapaev jokes were documented later, in the 1970s and 1980s (Melnichenko 2014: 808-821). At the same time, jokes about the abundance of Chapaev jokes appeared:

Pet'ka meets Chapaev covered with vomit.

"Where are you coming from, Vasily Ivanovich?"

"From the latest joke, Pet'ka".

(Melnichenko 2014: 820-821), 1986.

Just as with the Chapaev jokes, an outsize joke cycle about Stierlitz appeared in response to a popular TV series, The Seventeen Moments of Spring. The protagonist, acted by Viacheslav Tikhonov, is Soviet super-spy Colonel Maxim Isayev, who uses the cover name Stierlitz and impersonates an SS officer. The film was followed by an outburst of jokes about Stierlitz's character, mocking the spy's seemingly complex logic (Arkhipova 2013). Below is an example of a transgressive Stierlitz meta-joke which breaks the aforementioned fourth wall (see Section 2):

Stierlitz wakes up in a jail cell. "If a soldier in a Nazi uniform comes in, I'll say I'm SS Officer von Stierlitz. If he's in a Soviet uniform, I'll say I'm Colonel Isaev". A policeman comes in and says: "Well, well, Comrade Tikhonov, you sure tied one on last night, didn't you?"

(Graham 2003: 144), n.d.

It is harder to explain the sudden popularity of the jokes about the Chukchee people, an indigenous group living in the Chukotka Peninsula in Russia. Arkhipova (2015: 148) and Graham (2007) attribute their funniness to the fact that the word Chukchee itself sounds ridiculous in Russian (chukcha), thus leading to jokes about Chukchees' stupidity. As a response to the extreme popularity of Chukchee jokes, meta-jokes also formed, sometimes responsive to the broader genre of ethnic jokes:

A Chukchee decided to buy an accordion.

"Please sell the accordion to me!"

"We do not sell anything to Chukchees from jokes".

He changed his clothes, but the response was the same. He put a wig on, but the response was the same.

"How do you know that I am a Chukchee from the joke?"

"Because what you are trying to buy is not an accordion, but a radiator".

(Melnichenko 2014: 838), 1989.

Chukchee jokes also came in handy in 1984, when Konstantin Chernenko came to power as a leader of the Soviet Union. Officially the son of the Russian mother and a Ukrainian father, Chernenko was featured in many jokes that claimed him as a Chukchee. This might have been due to the alliteration of Chernenko's name and the Chukchee word bringing the two protagonists together. Along with the joke, a rumour circulated claiming that Chernenko was a Chukchee, and it is hard to say which genre developed first and which one influenced the other.

All the jokes starting with 'Ch' are banned: those about Chukchee, Chapaev, and Chernenko.

(Melnichenko 2014: 307), n.d.

The best Chukchee joke: in 1984, Chukchee became the leader of a big state.

(Melnichenko 2014: 307), 1984-03.1985. 
The following Chukchee joke harks back to the previously known danger of political joketelling still reiterated by meta-jokes:

Two Chukchees are sitting in a yaranga [a tent-like traditional house of some Northern Russian nomadic indigenous peoples]. One says, "Do you want me to tell a political joke to you?"

"Be quiet, in case we get deported".

(Melnichenko 2014: 604), 1984.

Another popular late Soviet joke cycle was that of the so-called Radio Armenia jokes (also known as Radio Yerevan jokes). Similar to elephant jokes in Anglophone culture, Radio Armenia jokes consist of a whimsical question (an absurdist riddle) and a completely unpredictable answer (unpredictable because of the absence of clues). Most Radio Armenia jokes were political in nature, ridiculing Soviet power (Kalbouss 1977; Draitser 1989: 8889). Melnichenko's collection introduces the earliest examples of Radio Armenian riddles from the 1930s. It was as early as the 1950s that the first meta-jokes about Radio Armenia appeared, making fun of their supposedly dissident characteristics:

"Is it true that the chief editor of Armenian radio sits in Yerevan?"

"It is true that he sits, but in Magadan" [camp in Siberia].

(Melnichenko 2014: 662), 1950s.

Radio Armenia jokes and meta-jokes became especially popular in the 1980s and continued to feature the most widespread trope of Soviet meta-jokes, namely joke-telling resulting in persecution:

A question to Radio Armenia, "Why can't we hear you?"

"We used to broadcast from Yerevan, but now we broadcast from Magadan".

(Melnichenko 2014: 662), 1987.

Some meta-jokes go as far as to mixing several of the joke topics described above together:

An average yearly joke: Lenin meets Chapaev in Prague and asks him, "Haim [one of the most frequent names for a Jew in the jokes], have you already submitted your application to OVIR [the division of militia dealing with applications for emigration]?"

(Melnichenko 2014: 181), 1970.

Chukchee walks around Moscow with a seal on a leash. He crosses the road against the red lights. A militiaman tries to arrest him. Chukchee then says,

"You cannot arrest me: I am the most famous person in the country. People always tell jokes about me, don't you know?"

"Sorry, Vasily Ivanovich [Chapaev], I did not recognise you".

(Melnichenko 2014: 841), 1984-1985.

A computer compiles the most typical joke of 1976: Vasily Ivanovich visits Anka and finds Pet'ka and Stierlitz seeing her. Both are Jews.

(Melnichenko 2014: 820), 1981.

The latter joke is illustrative of one of the key functions of meta-jokes as described by Graham (2003: 145): they entail a generic feedback mechanism that identifies particularly

\footnotetext{
${ }^{4}$ In another version, the first Chukchee asks, "Do you want to hear a joke about Chernenko?"
} 
hyper-productive cycles or motifs by ironically laying bare their textuality. Related to this are the examples of meta-jokes on the "shortest jokes", producing humour in a phrase which is as short as possible:

The shortest joke: "Two ministers meet in a trolleybus..."

(Melnichenko 2014: 122), 1986.

The shortest joke: "Communism." The longest joke: "The program for building communism, accepted at the 22th Party Congress".

(Melnichenko 2014: 159), 1962.

"What is the shortest joke?"

"A five-year plan". 6

(Melnichenko 2014: 496), 1929.

Unlike previous meta-jokes which uncovered, first, the repressiveness of the regime, and, second, the hypocrisy of the seeming liberalisation, the late Soviet jokes document the shift to non-political topics, which, indeed might have been the sign of liberalization this time. The danger of joke-telling declined (although the fear of it did not disappear completely as still some meta-jokes show), which is why the space for non-political jokes cleared up. Metajokes of the late Soviet era evidence which of these jokes were particularly popular: that about Chapaev, Stierlitz, and Chukchee. At the same time, the late Soviet meta-joke mastered the conciseness by reflecting on certain topics in the briefest way possible.

Whether in a popular or an academic discussion, there is a widespread idea that Soviet jokes were in essence the Golden Age of political joke-telling and that afterwards the political jokes went almost extinct. However, the materials from the post-Soviet countries demonstrate the opposite: not only the political jokes are ubiquitous, but the meta-jokes about political jokes are also still abundant. In the following Section, I give a brief overview of the example of post-Soviet political meta-jokes in Russia and Belarus just some among the many.

\section{Post-Soviet meta-jokes: continuity and novelties}

The jokes about Putin have been popular in Russia from the very beginning of his power (Arkhipova 2012). They may, for instance, refer to the old Soviet joke cycle about Vovochka, a Russian equivalent of Little Johnny, a trickster boy, often giving dirty or inappropriate comments in the jokes (see also Section 3.1). Vovochka is a nickname for Vladimir, which is why the joke cycle acquired new meaning when Putin came to power. As a popular meta-joke says:

The first bill issued by the President of Russian Federation: to consider all Vovochka jokes political.

(Hristova 2008: 199-200)

This joke reminds of the close intertextual links in between two similar joke cycles: about Chernenko and Chukchee. Another joke refers to the Stierlitz joke cycle from Soviet times,

\footnotetext{
${ }^{5}$ The joke refers to the impossibility of high ranks of power to live like ordinary people and, for instance, use public transport.

${ }^{6}$ The joke refers to a list of economic goals the Soviet state under Stalin slated for completion within five years, and known to be almost impossible to achieve.
} 
linking Putin's past as a secret police agent to the popular joke protagonist, who was also a spy.

And yet one more reason why Putin is our president: in him, two favourite characters from the world of jokes are merged - Stierlitz and Vovochka.

(Cassiday \& Johnson 2010: 691)

As in Russia, the tradition of meta-jokes continues in the post-Soviet state of Belarus governed by one and the same president, Alexander Lukashenko, since 1994. The Soviet background and current situation of non-democratic government in Belarus offers an ideal backdrop against which jokes (and consequently meta-jokes) can emerge and flourish. Below are just some of the meta-jokes I recorded during my fieldwork there:

A toast. A new prisoner is pushed into the cell. "Why are you here?" the others ask.

"For a joke".

"Tell us the joke!"

He tells a joke, a new court case is started for him, he is sentenced to additional years of imprisonment, and pushed into a cell.

"Why are you here?"

"For a joke!"

"Tell us the joke!"

He tells it, and so on. So, let's drink to the vigilance of Soviet prisoners!

(recorded in Minsk, 2014)

Two friends walk in the street, and a man in plain clothes follows them. One friend says to the other, "Do you want me to tell you a political joke?"

"Yes".

"Do you know what the difference is between Lukashenko [the president] and a donkey?"

A man who has been following them interrupts: "What is the difference?"

The one who was trying to tell a joke answers fearfully, "No, there is no difference, no!"

(recorded in Minsk, 2013)

Someone asks Alexander Lukashenko, "Do you have a sense of humour?"

"Of course! For example, tell the latest joke about me!"

"I cannot remember the punchline of it..."

"It does not matter, you may start! You will have a lot of time to remember the punchline [while serving a prison term]!"

(recorded in Vitebsk, 2014)

Both Soviet and post-Soviet jokes, and especially meta-jokes, serve as perfect metaphors for the regime: rather than going into lengthy explanations of why it is authoritarian, people tell a meta-joke about the fear of telling jokes, since this is a much sharper and laconic way to reflect on these issues. The ultimate example of such a function of meta-jokes is the so-called "orphaned punchline" - a recognisable part of the joke used without the rest of the joke it belongs to (Kelley 2015: 215). I have been able to document this rare phenomenon in Belarus very frequently, in particular when people referred to the old Soviet meta-joke about Comrade Major, the secret service agent surveilling people everywhere.

Four people in the train compartment tell political jokes to one other. One of the joke-tellers decided to make a joke and frighten his companions a bit. He leaves the compartment, goes up to the train attendant, and asks her to bring several glasses of tea to their compartment in a few minutes. Then he comes back to the compartment and says to his travel companions, "We are 
telling political jokes here, and it turns out that we are being recorded. Don't you believe me?" Then he lifted the cover of one of the beds and said, "Comrade Major, please order four glasses of tea for compartment number five". Straight away, the compartment door opens, and the train attendant brings in the tea. His travel companions are shocked, they stop talking, and go to sleep. In the morning, the man wakes up all alone in the train compartment. He goes back to the train attendant and asks, "But where are my travelling companions?"

The attendant replies, "They were arrested. But Comrade Major really liked your tea joke".7

(Melnichenko 2014: 361-362), 1980.

This joke is still retold and widely known in Belarus, as well as in other post-Soviet countries, to the extent that the Comrade Major from the joke becomes a highly recognisable reference point for the fear of surveillance. For instance, a Belarusian dissident told me in an interview, "They may listen to all mobile phone calls. It does not mean that the Major is now listening to us, but, as our phones now have microphones, they are switched on and any Comrade Major may listen to what we are talking about" (recorded in Vitebsk in 2012). Just a few words, such as Comrade Major, may metonymically stand in for a long description of how an individual is afraid of surveillance. It is essential that listeners share in the knowledge of the Comrade Major meta-joke to get this intertextual link: a reminder of the symbolic boundaries humour can demarcate (see Section 2). I once received an even more curious commentary, in the shape of a meta-joke referring to a Comrade Major meta-joke. After I asked permission from another respondent to record his interview and took the recorder out of my bag, he grinned: "Comrade Major, our president is very good, everything in our country is good". This was quite a unique case of using a joke about a joke for a joke, a multi-level meta-joke.

The Belarusian examples of meta-jokes probably comprise just a few from a huge postSoviet meta-joking tradition which is under-researched. This case reminds us of how much there still is to document about meta-jokes: unlike Soviet times, one can now mostly record them in their contexts, be that narrative or conversation, and even double- or multi-level meta-jokes. What would be even more fascinating would be to record the folk metacommentary on meta-jokes.

\section{Conclusions}

The term meta-jokes has been understood in two ways: (1) to underline the intertextuality inherent in jokes, always referring to actual realities, and (2) to define jokes about jokes. In this article, I have mostly related to the meta-jokes in the second understanding and analysed Soviet and post-Soviet meta-jokes. Meta-jokes usually appear as a response to an abundance of ordinary jokes, and the Soviet example again proves this statement. Although this characteristic seems to be quite universal for meta-jokes all over the world, their local instances may feature unique peculiarities. What makes Soviet meta-jokes strikingly different from their Anglophone counterparts, for instance, is that the Soviet meta-jokes were mainly political, especially so in the most repressive times. Given the lack of meta-data on the context of the Soviet joke-telling, the situations and social settings in which people were telling jokes, meta-jokes may provide valuable commentary on the Soviet joking tradition.

Soviet jokes emerged along with the Revolution, but they seem to have become especially plenty in the Stalinist era. This is when the meta-jokes developed, too, mainly

${ }^{7}$ In another version, the joke is set in a hotel, a man whispers his request for tea to the Major into the ashtray after asking a receptionist to bring tea into the hotel room. 
reflecting on the fears of political persecution in the times of GULAG. In this era, meta-jokes became cautionary tales on what may happen to careless joke-tellers if they are surveilled or reported by KGB agents or friends. Meta-jokes of this time did not only convey lessons: as some life stories show, they may have shaped crucial decisions by encouraging people to pursue ways to leave the repressive country. Meta-jokes documented the incongruity between the official rhetoric and the reality, for instance, the public condemnation of anti-Semitism by the officials opposed to actual ubiquitous anti-Semitism.

Khrushchev's Thaw is known to have brought some relief with regards to repressiveness, however, the meta-jokes of this time demonstrate the ambiguity and hypocrisy of the seeming democratisation. The fears of joke-telling remained, and meta-jokes reflecting on this question the historical stereotypes. New topics emerged, too, such as laughing at the ideologically approved official political humour imposed on people. In this period, metajokes also evolve from documenting incongruity between the official claims and the reality to openly referring to the Soviet political discourse as just an absurd joke.

The abundance of jokes in the Soviet times fostered meta-jokes about it as well as rumours about who made up the jokes, especially widespread in the late Soviet period. Late Soviet jokes still document the historical realities, such as shortages, yet they also engage with new topics. Meta-jokes of the late Soviet period documented the shift of the humour to non-political topics, as meta-jokes now also revisited some persistent non-political joke cycles: about Jews, Chukchees, Chapaev, etc. One of the explanations may involve the relative liberalisation of the late Soviet Union: political jokes were not that essential as a vent for frustration anymore. The space for other, non-political themes cleared up in the jokes and, consequently, in meta-jokes, too.

The post-Soviet meta-jokes illustrate that even a primarily non-political joke cycle may be used for developing political joke topics. Such are, for instance, the meta-jokes merging the joke cycles about Vovochka and Putin. Moreover, the contemporary field materials from Belarus allow me to show how meta-jokes are not necessarily of the classic narrative type: these may be the ephemeral conversational meta-jokes that make use of the popular political jokes. A rare example I documented in Belarus is making a joke about a joke for a joke, a multi-level meta-joke. Such forms might have well circulated in the Soviet Union, too, but simply nobody recorded them. The abundance and novelties in post-Soviet meta-jokes do reassure humour researchers: political jokes are very much alive; they remain a vibrant tradition despite the popular idea that they are extinct. Moreover, they remind us of the necessity of the study of verbal jokes (as opposed to the overarching academic interest towards the study of the Internet humour): some peculiarities of meta-jokes can only be observed in oral discourse.

Given that the majority of (still rare) records of the Soviet jokes do not have any context with them, the meta part of meta-jokes can serve as such a context, as well as serving as oral criticism and as commentary on a variety of processes. Meta-jokes are in a way, archival resources: they serve as the records of how joke traditions change, which joke cycles are particularly productive, and how people treat different kinds of humour; in other words, which kinds of humour succeeds and which fails. Meta-jokes document the position of the jokes and joke-tellers in the regime, reflect upon the joking traditions and the attitude of the regime to them, and flag up the changes brought in by each new political leader. Meta-jokes are not only illustrative of how much the Soviet jokes were embedded in everyday life, but may also provide the basis for the inventory of the most popular joke cycles. Both earlier and contemporary meta-jokes may serve as informal folk accounts or oral histories of different political realities, as biographical narratives would sometimes do. In a way, just like historical archives, meta-jokes provide historical evidence, in the most concise way possible though. 


\section{Acknowledgements}

This research was supported by personal research funding from the Estonian Research Council PSG48 'Performative Negotiations of Belonging in Contemporary Estonia $(1.01 .2018-31.12 .2021)^{\prime}$.

\section{References}

Adami, E. (2012). 'The rhetoric of the implicit and the politics of representation in the age of copy-and-paste'. Learning, Media, and Technology 37 (2), pp. 131-144.

Alexievich, S. (2017). The Unwomanly Face of War: An Oral History of Women in World War II (transl. by R. Pevear \& L. Volokhonsky). New York: Random House.

Arkhipova, A. (2012). 'Jokes about Putin and the elections ten years on, or, is there a folklore of the "Snow Revolution"?'. Forum for Anthropology and Culture 8, pp. 303-336.

Arkhipova, A. (2013). Shtirlitz shel po koridoru: kak my pridumyvaem anekdoty [Stierlitz Was Walking Down the Corridor: How Do We Invent Jokes]. Moscow: RGGU.

Arkhipova, A. (2015). Radio OBS, ptitsa oblomingo i drugie iazykovye igry v sovremennom folklore [Radio One Woman Said, Oblomingo Bird, and Other Wordplay Cases in Contemporary Folklore]. Moscow: Forum.

Arkhipova, A. \& Melnichenko, M. (2011). Anekdoty o Staline: teksty, kommentarii, issledovaniia [Jokes about Stalin: Texts, Commentary, Research]. Moscow: OGI.

Bakhtin, V. (1997). 'Anekdoty nas spasali vsegda [Jokes always saved us]', in Strelianyi, A., Sapgir, G., Bakhtin, V., Ordynskii, N. (comps.), Samizdat veka [Samizdat of the Century], Minsk/Moscow: Polifakt, pp. 799-818.

Banc [pseud.] \& Dundes, A. (1986). First Prize: Fifteen Years! An Annotated Collection of Romanian Political Jokes. Rutherford: Fairlegh Dickinson University Press.

Bauman, R. (2004). A World of Others' Words: Cross-Cultural Perspectives on Intertextuality. Malden: Blackwell.

Briggs, C. \& Bauman, R. (1992). 'Genre, intertexuality and social power'. Journal of Linguistic Anthropology 2 (2), pp. 131-172.

Cassiday, J. A. \& Johnson, E. D. (2010). 'Putin, Putiniana and the question of a post-Soviet cult of personality'. The Slavonic and East European Review 88 (4), pp. 681-707.

Dobrenko, E. (2014). 'From the compiler'. Russian Studies in Literature 50 (2), pp. 6-7.

Draitser, E. (1989). 'Comparative analysis of Russian and American humour'. Meta 34 (1), pp. 88-90.

Duff, P. A. (2004). 'Intertextuality and hybrid discourses: The infusion of pop culture in educational discourse'. Linguistics and Education 14 (3-4), pp. 231-276.

Dundes, A. (2007). The Meaning of Folklore. The Analytical Essays of Alan Dundes (ed. by S. J. Bronner). Logan: Utah State University Press.

Finkin, J. (2009). 'Jewish jokes, Yiddish storytelling, and Sholem Aleichem: A discursive approach'. Jewish Social Studies 16 (1), pp. 85-110.

Galanter, M. (2005). Lowering the Bar: Lawyer Jokes and Legal Culture. Madison: University of Wisconsin Press.

Gasparov, B. (2010). Speech, Memory, and Meaning: Intertextuality in Everyday Language. Berlin: De Gruyter.

Graham, S. B. (2003). A Cultural Analysis of the Russo-Soviet Anekdot. Doctoral Dissertation, University of Pittsburgh.

Graham, S. B. (2007). 'Anekdoticheskii tsikl o chukchah: otkuda, odnako? [The joke cycle about Chukchees: where is it actually from?]'. Zhivaia starina 4, pp. 33-35. 
Hale, A. (2018). 'There is an after-life (for jokes, anyway): The potential for, and appeal of, "immortality" in humour'. Humour: International Journal of Humour Research 31 (3), pp. 507-538.

Hariman, R. (2008). 'Political parody and public culture'. Quarterly Journal of Speech 94 (3), pp. 247-272.

Hristova, D. S. (2008). 'Negotiating reality with "anekdoty": Soviet vs. post-Soviet humour lore'. Russian Language Journal 58, pp. 187-210.

Kalbouss, G. (1977). 'On "Armenian riddles" and their offspring "Radio Erevan"'. Slavic and East European Journal 21 (3), pp. 447-449.

Kelley, G. (2015). “"The Joke's on us". An analysis of metahumour', in Foster, M. D. \& Tolbert, J. A. (eds.), The Folkloresque: Reframing Folklore in a Popular Culture World, Logan: Utah State University Press, pp. 205-220.

Kozlov, V. (2002). 'Kramola: inakomyslie v SSSR vo vremena Khrushcheva i Brezhneva [Sedition: Dissidence in the USSR in the times of Khrushchev and Brezhnev]'. Obshchestvennye nauki i sovremennost' [Social Sciences and Modernity] 3, pp. 75-88.

Kristeva, J. (1980). Desire in Language. New York: Columbia University Press.

Kuipers, G. (2009). 'Humour styles and symbolic boundaries'. Journal of Literary Theory 3 (2), pp. 219-239.

Limón, J. E. (1983). 'Legendry, metafolklore, and performance: A Mexican-American Example'. Western Folklore 42 (3), pp. 191-208.

Luray, M. (1957). 'Bitter wit from Hungary'. New York Times, section 6, p. 16.

Melnichenko, M. (2014). Sovetskii anekdot: ukazatel' siuzhetov [Soviet anecdotes. A Plot Index]. Moscow: Novoe literaturnoe obozrenie.

Norrick, N. R. (1989). 'Intertextuality in humour'. Humour: International Journal of Humour Research 2 (2), pp. 117-140.

Oring, E. (2004). 'Risky business: Political jokes under repressive regimes'. Western Folklore 63 (3), pp. 209-236.

Raskin, V. (1985). Semantic Mechanisms of Humour. Springer: Heidelberg.

Smith, M. (2009). 'The art of practical jokes'. Paper presented at the 2009 meeting of the American Folklore Society in Boise, Idaho, October 2009.

Stalin, J. (1954). 'Reply to an inquiry of the Jewish News Agency in the United States', in Works, Vol. 13, July 1930-January 1934. Moscow: Foreign Languages Publishing House.

Stein, M. B. (1989). 'The politics of humour: The Berlin Wall in jokes and graffiti'. Western Folklore 48 (2), pp. 85-108.

Terts, A. (1978). 'Anekdot v anekdote [A joke in a joke]'. Sintaksis 1, pp. 77-95.

The Colbert Report (2013). 1-283, December 12.

The Guardian (2003). 'They're not laughing now'. Retrieved March 23, 2019 from https://www.theguardian.com/uk/2003/dec/29/arts.artsnews1.

Tsakona, V. (2018). 'Intertextuality and/in political jokes'. Lingua 203, pp. 1-15.

Waterlow, J. (2018). It's Only a Joke, Comrade! Humour, Trust and Everyday Life under Stalin. Oxford: CreateSpace Independent Publishing Platform. 